\title{
PENGARUH PEMBINAAN, PELATIHAN, DAN PENGEMBANGAN TERHADAP KINERJA KARYAWAN \\ (Studi Pada Karyawan Pengguna Komputer Dengan Sistem Operasi Ubuntu Di PT. Pegadaian [Persero] Kanwil I Medan)
}

\author{
Nico Damanik \\ Alumni Jurusan Manajemen Fakultas Ekonomi Universitas Negeri Medan \\ T. Teviana \\ Dosen Jurusan Manajemen Fakultas Ekonomi Universitas Negeri Medan
}

\begin{abstract}
Abstrak
Penelitian bertujuan untuk mengetahui pengaruh pembinaan, pelatihan, dan pengembangan terhadap kinerja karyawan (studi pada karyawan pengguna komputer dengan sistem operasi Ubuntu di PT. Pegadaian [Persero] Kanwil I Medan). Penelitian dilaksanakan di PT. Pegadaian (Persero) Kanwil I Medan.Sampel penelitian berjumlah 34 responden.Pengambilan sampel menggunakan sampling jenuh/ sensus, artinya seluruh populasi digunakan sebagai sampel. Teknik pengumpulan data yang digunakan adalah kuesioner yang pengukurannya menggunakan skala Likert dan diolah secara statistik menggunakan metode analisis regresi berganda dengan persamaan $Y=a+b_{1} X_{1}+b_{2} X_{2}+b_{3} X_{3}+e$ melalui program IBM SPSS Statistics 23. Hasil penelitian menunjukkan variabel pembinaan $\left(X_{1}\right)$, pelatihan $\left(X_{2}\right)$, dan pengembangan $\left(X_{3}\right)$ secara simultan berpengaruh signifikan terhadap kinerja karyawan (Y). Hal ini terlihat dari $F_{\text {hitung }}=18,723$ dan $F_{\text {tabel }}=2,975$, sehingga $F_{\text {hitung }}>F_{\text {tabel }}$ signifikansi 0,000. Besar pengaruh variabel pembinaan, pelatihan dan pengembangan terhadap kinerja karyawan adalah $69,2 \%$ ditunjukkan dengan nilai $R^{2}$ yaitu 0,692. Sedangkan secara parsial pembinaan memiliki pengaruh terhadap kinerja karyawan dengan $t_{\text {hitung }}>t_{\text {tabel }}$ yaitu 2,077>2,056 signifikansi 0,038<0,05, pelatihan berpengaruh terhadap kinerja karyawan dengan $t_{\text {hitung }}>t_{\text {tabel }}$ yaitu 2,951>2,056 signifikansi $0,007<0,05$, dan variabel pengembangan berpengaruh terhadap kinerja karyawan dengan $t_{\text {hitung }}>t_{\text {tabel }}$ yaitu 2,092 $>2,056$ signifikansi 0,046<0,05. Persamaan struktural $Y=-2,136+0,178 X_{1}+0,583 X_{2}+0,373 X_{3}$. Dengan demikian dapat disimpulkan pembinaan, pelatihan, dan pengembangan mempunyai pengaruh positif dan signifikan terhadap kinerja karyawan (studi pada karyawan pengguna komputer dengan sistem operasi Ubuntu di PT. Pegadaian [Persero] Kanwil I Medan), secara simultan maupun parsial.
\end{abstract}

Kata Kunci: Pembinaan, Pelatihan, Pengembangan, Kinerja Karyawan

\section{PENDAHULUAN}

PT. Pegadaian (Persero)

Kanwil I Medan adalah sebuah BUMN di Indonesia yang usaha intinya adalah bidang jasa penyaluran kredit kepada masyarakat atas dasar hukum gadai. Di dalam menjalankan aktivitas perusahaan setiap karyawan menggunakan komputer dengan sistem operasi Microsoft Windows dan Aplikasi perkantoran Microsoft
Office sebagai alat bantu dalam melaksanakan tugas-tugas perkantoran. Pada tahun 2007 terjadi perubahan besar pada penggunaan teknologi penggunaan sistem operasi (OS) Microsoft Windows menjadi Ubuntu.Perubahan dilakukan secara bertahap dan pada tahun 2012.Perubahan tersebut didasari oleh biaya pembelian lisensi penggunaan 
sistem operasi Microsoft Windows yang cukup besar.

Ubuntu adalah sistem operasi lengkap berbasis Linux, tersedia secara bebas, dan mempunyai dukungan baik yang berasal dari komunitas maupun tenaga ahli profesional.Nama Ubuntu berasal dari filosofi dari Afrika Selatan yang berarti "kemanusiaan kepada sesama".Proyek Ubuntu resmi disponsori oleh Canonical Ltd. yang merupakan sebuah perusahaan yang dimiliki oleh pengusaha Afrika Selatan Mark Shuttleworth (Wikipedia, 4 Januari 2015).

Perubahan tersebut berpengaruh terhadap aktivitas kerja karyawan pada PT. Pegadaian (Persero) Kanwil I Medan.Karyawan yang sudah terbiasa bekerja dengan menggunakan sistem operasi Windows harus bekerja menggunakan sistem operasi Ubuntu.Tampilan Antar muka pengguna grafis yang tidak familiar dan bertolak belakang dengan Microsoft Windows menyulitkan penggunaan Ubuntu oleh karyawan di pada PT. Pegadaian (Persero) Kanwil I Medan.

Berdasarkan observasi yang penulis lakukan terhadap tiga orang karyawan di PT. Pegadaian (Persero) Kanwil I Medan, ketiga karyawan merasakan terkadang mengalami kesulitan menggunakan sistem operasi Ubuntu dalam mengerjakan tugas-tugasnya.Alasannya para karyawan sudah terbiasa menggunakan sistem operasi Microsoft Windows yang sudah dari dulu digunakan bahkan sebelum mereka bekerja di PT. Pegadaian mereka juga menggunakan komputer atau laptop dengan sistem operasi Microsoft Windows.Hal tersebut membuat karyawan harus mempelajari penggunaan sistem operasi Ubuntu agar dapat bekerja dengan baik, untuk kebutuhan itu perusahaan memberikan bentuk pembinaan, pelatihan dan pengembangan dalam penggunaan sistem operasi Ubuntu. Pembinaan

karyawan diharapkan dapat membantu karyawan dalam penggunaan perangkat lunak tersebut dalam melaksanakan tugas-tugas dan memecahkan masalah-masalah yang terjadi selama bekerja (troubleshooting).Pelatihan di PT. Pegadaian (Persero) Kanwil I Medan dalam studi ini adalah pelatihan teknik pengoperasian Ubuntu, penggunaan Aplikasi Perkantoran LibreOffice serta pelatihan menggunakan Sistem Informasi online aplikasi corebussines PASSION dan MIS. Pengembangan di PT. Pegadaian (Persero) Kanwil I Medan dalam studi ini adalah diberikan kepada karyawan yang akan menduduki suatu tugas atau jabatan baru di perusahaan dalam penggunaan sistem informasi online, seperti kenaikan jabatan dari penaksir muda menjadi asisten atau manajer sehingga harus mempelajari penggunaan sistem informasi online yang mendukung pekerjaannya sesuai dengan jobdescription sebagai seorang pengawas atau pemimpin.

\section{LANDASAN TEORI Kinerja Karyawan}

Menurut Sinambela, dkk (2012:136) mengemukakan bahwa "Kinerja karyawan didefinisikan sebagai kemampuan pegawai dalam melakukan sesuatu keahlian tertentu". Kinerja karyawan sangatlah perlu, 
sebab dengan kinerja ini akan diketahui seberapa jauh kemampuan karyawan dalam melaksanakan tugas yang dibebankan kepadanya. Untuk itu diperlukan penentuan kriteria yang jelas dan terukur serta ditetapkan secara bersama-sama yang dijadikan sebagai acuan.

\section{Pembinaan Karyawan}

Menurut Jaques dan Clement (dalam Nugroho, 2012:1), "Pembinaan terhadap karyawan/bawahan harus merupakan bagian dari aktivitas harian seorang atasan.Pembinaan bisa dalam bentuk berbagi pengetahuan, keterampilan dan pengalaman yang berkaitan dengan pekerjaan karyawan”.

\section{Pelatihan}

Pelatihan Menurut Salim (2014:7) "Pelatihan adalah suatu usaha dalam rangka memberikan ilmu dan pengetahuan mengenai hal-hal tertentu yang dibawakan oleh seorang trainer yang menguasai materi tersebut". Menurut Hamalik (2007:10) "Pelatihan adalah suatu fungsi manajemen yang perlu dilaksanakan terus-menerus dalam suatu organisasi yang dilaksanakan secara berkesinambungan, bertahap dan terpadu untuk mencapai tujuan tertentu terkait dengan upaya pencapaian tujuan organisasi".

\section{Pengembangan}

Sunyoto(2012:145),

menyatakan "Pengembangan adalah sebagai penyiapan individu untuk memikul tanggung jawab yang berbeda atau yang lebih tinggi didalam organisasi, yang biasanya berhubungan dengan peningkatan kemampuan intelektual atau emosional yang diperlukan untuk menunaikan pekerjaan yang lebih baik".

HASIL DAN PEMBAHASAN

PENELITIAN

Hasil Penelitian

Analisis Regresi Linier Berganda

Berdasarkan perhitungan

menggunakan SPSS Statistics 23, regresi antara variabel pembinaan, pelatihan dan pengembangan terhadap variabel kinerja karyawan adalah sebagai berikut:

Tabel 1. Koefisien Regresi

\begin{tabular}{|l|c|}
\hline \multicolumn{1}{|c|}{ Variabel } & B \\
\hline Konstanta & $-2,136$ \\
\hline Pembinaan & 0,178 \\
\hline Pelatihan & 0,583 \\
\hline Pengembangan & 0,373 \\
\hline
\end{tabular}

Sumber: Hasil Pengolahan Data, 2016

Dari pengolahan data, maka

dapat dibuat persamaan regresi yaitu:

$$
Y=-2,136+0,178 X_{1}+0,583 X_{2}+
$$$$
\mathbf{0 , 3 7 3} \mathrm{X}_{3}
$$

Persamaan regresi dapat

dijelaskan sebagai berikut:

a. Konstan sebesar $-2,136$ menyatakan bahwa jika tidak ada variabel pembinaan $\left(\mathrm{X}_{1}\right)$, pelatihan $\left(\mathrm{X}_{2}\right), \quad$ dan pengembangan $\left(\mathrm{X}_{3}\right)$ maka nilai kinerja $(\mathrm{Y})$ adalah -2,136.

b. Koefisien regresi variabel pembinaan $\left(\mathrm{X}_{1}\right)$ sebesar 0,178 , artinya jika pembinaan mengalami kenaikan 1 satuan, maka kinerja (Y) akan mengalami peningkatan sebesar 0,178.

c. Koefisien regresi variabel pelatihan $\left(\mathrm{X}_{2}\right)$ sebesar 0.583 , artinya jika pembinaan mengalami kenaikan 1 satuan, maka kinerja (Y) akan 
mengalami peningkatan sebesar 0,583.

d. Koefisien regresi variabel pengembangan $\left(\mathrm{X}_{3}\right)$ sebesar 0.373 , artinya jika pembinaan mengalami kenaikan 1 satuan, maka kinerja (Y) akan mengalami peningkatan sebesar 0,373 .

\section{Pengujian Hipotesis}

Pengujian Hipotesis Secara Parsial Menggunakan Uji t

Tabel 2. Hasil Uji t

\begin{tabular}{|l|c|c|}
\hline Variabel Bebas & $\begin{array}{c}\text { T } \\
\text { Hitung }\end{array}$ & $\begin{array}{c}\text { Signifi } \\
\text { kansi }\end{array}$ \\
\hline Pembinaan & 2,077 & 0,038 \\
\hline Pelatihan & 2,951 & 0,007 \\
\hline Pengembangan & 2,092 & 0,046 \\
\hline
\end{tabular}

Sumber: Hasil Pengolahan Data, 2016 Hasil analisis uji $t$ adalah sebagai berikut:

1) Nilai thitung pada variabel pembinaan (X1) yang diperoleh yaitu $2,077>2,056$ dan taraf signifikan $0,038<$ 0,05, maka mengindikasikan bahwa $\mathrm{H}_{1}$ diterima, artinya pembinaan berpengaruh positif terhadap kinerja karyawan.

2) Nilai thitung pada variabel pelatihan yang diperoleh yaitu $2,951>2,056$ dan taraf signifikan $0,007<0,05$, maka mengindikasikan bahwa $\mathrm{H}_{2}$ diterima, artinya pelatihan berpengaruh positif terhadap kinerja karyawan.

3) Nilai thitung pada variabel pengembangan yang diperoleh yaitu $2,092>2,056$ dan taraf signifikan $0,046<0,05$, maka mengindikasikan bahwa $\mathrm{H}_{3}$ diterima, artinya pengembangan berpengaruh positif terhadap kinerja karyawan.

\section{Pengujian Hipotesis Secara Simultan Menggunakan Uji-F Tabel 3. Uji ANOVA}

\begin{tabular}{|c|c|c|}
\hline F Tabel & F Hitung & Signifikan \\
\hline 2.975 & 19,494 & 0,000 \\
\hline
\end{tabular}

Sumber: Hasil Pengolahan Data, 2016

Berdasarkan tabel 3. diperoleh $\mathrm{F}_{\text {hitung }}$ sebesar 19,494 dengan taraf signifikansi $95 \%$ dan $\alpha=0,05$ serta derajat kebebasan (degree of freedom) dengan ketentuan $\mathrm{df} 1=\mathrm{k}-$ 1 yaitu df $1=4-1=3$ dan df $2=n-k$ yaitu df $2=30-4=26$. Maka dengan ketentuan tersebut diperoleh $\mathrm{F}_{\text {tabel }}=$ 2.975 .

Dengan demikian diperoleh $\mathrm{F}_{\text {hitung }}=19,494$ dan $\mathrm{F}_{\text {tabel }}=2.975$. karena $\quad F_{\text {hitung }}>\quad F_{\text {tabel }}$ dan tingkat signifikan yaitu $0,000<0,005$ maka $\mathrm{H} 4$ diterima, sehingga dapat disimpulkan bahwa pembinaan $\left(\mathrm{X}_{1}\right)$, pelatihan $\left(\mathrm{X}_{2}\right)$, dan pengembangan $\left(\mathrm{X}_{3}\right)$ berpengaruh secara simultan terhadap kinerja karyawan (studi pada karyawan pengguna komputer dengan sistem operasi Ubuntu di PT. Pegadaian [Persero] Kanwil I Medan).

\section{Koefisien Determinasi (R Square)} Tabel 4. Model Summary ${ }^{b}$

\begin{tabular}{|c|c|}
\hline $\mathrm{R}$ & R Square \\
\hline $0,832^{\mathrm{a}}$ & 0,692 \\
\hline
\end{tabular}

Sumber: Hasil Pengolahan Data, 2016

Dapat dilihat besar angka $\mathrm{R}^{2}$ adalah 0,692 , yang artinya variabel $\mathrm{X}_{1}, \mathrm{X}_{2}$, dan $\mathrm{X}_{3}$ menjelaskan pengaruh terhadap variabel $\mathrm{Y}$ sebesar $69,2 \%$ $\left(\mathrm{R}^{2} \times 100 \% ; 0,692 \times 100 \%=69,2 \%\right)$ sedangkan sisanya $30,8 \%(100 \%$ - 
$\mathrm{R}^{2}$ ) dijelaskan oleh variabel-variabel diluar model penelitian ini.

\section{Hasil Pembahasan}

Hasil Penelitian

Variabel

Pembinaan $\left(\mathbf{X}_{1}\right)$

Dengan melihat hasil penelitian yang dilakukan, diperoleh pengujian hipotesis pembinaan terhadap kinerja karyawan menghasilkan $t_{\text {hitung }}>t_{\text {tabel }}$ sebesar $2,077>2,056$ dengan signifikan $0,038<0,05$. Selain itu, hasil penelitian menunjukkan nilai koefisien regresi 0,178.Sehingga dapat diartikan bahwa pada taraf signifikansi $5 \%$ pembinaan memiliki pengaruh positif dan signifikan terhadap kinerja karyawan.

\section{Hasil Penelitian Variabel Pelatihan $\left(\mathbf{X}_{2}\right)$}

Dengan melihat hasil penelitian yang dilakukan, diperoleh pengujian hipotesis pelatihan terhadap kinerja karyawan menghasilkan $t_{\text {hitung }}>t_{\text {tabel }}$ sebesar $2,951>2,056$ dengan signifikan $0,007<0,05$. Selain itu, hasil penelitian menunjukkan nilai koefisien regresi 0,583. Sehingga dapat diartikan bahwa pada taraf signifikansi $5 \%$ pembinaan memiliki pengaruh positif dan signifikan terhadap kinerja karyawan.

$\begin{array}{lr}\text { Hasil Penelitian } & \text { Variabel } \\ \text { Pengembangan }\left(X_{3}\right) & \\ \text { Dengan melihat } & \text { hasil }\end{array}$
penelitian yang dilakukan, diperoleh pengujian hipotesis pengembangan terhadap kinerja karyawan menghasilkan $t_{\text {hitung }}>t_{\text {tabel }}$ sebesar $2,092>2,056$ dengan signifikan $0,046<0,05$. Selain itu, hasil penelitian menunjukkan nilai koefisien regresi 0,373.Sehingga dapat diartikan bahwa pada taraf signifikansi $5 \%$ pengembangan memiliki pengaruh positif dan signifikan terhadap kinerja karyawan. Berdasarkan kriteria tersebut, nilai $t_{\text {hitung }}$ yang diperoleh data tabel coefficients yaitu 2,092 > 2,056 dan taraf signifikan $0,046<0,05$, maka $\mathrm{H}_{3}$ diterima, artinya pengembangan berpengaruh positif terhadap kinerja karyawan.

\section{Hasil Penelitian Variabel Kinerja (Y)}

Dengan melihat hasil penelitian yang dilakukan, didapat persamaan linear berganda $\mathrm{Y}=-2,136$ $+0,178 \mathrm{X} 1+0,583 \mathrm{X} 2+0,373 \mathrm{X} 3$, memberikan permahaman bahwa nilai konstanta sebesar -2,136 satuan menunjukkan jika PT. Pegadaian (Persero) Kanwil I Medan tidak mengadakan pembinaan, pelatihan, dan pengembangan maka kinerja yang dimiliki karyawan akan bernilai negatif, dengan demikian untuk meningkatkan kinerja karyawan diperlukan pembinaan, pelatihan, dan pengembangan.

\section{PENUTUP}

Berdasarkan hasil analisis yang diperoleh dan pembahasan dalam penelitian ini, terdapat beberapa kesimpulan yaitu sebagai berikut:

1. Setelah dilakukan uji hipotesis secara parsial (Uji t) variabel pembinaan $\left(\mathrm{X}_{1}\right)$ secara parsial berpengaruh terhadap kinerja karyawan (Y). Hal ini mendukung hipotesis yang menyatakan bahwa "Pembinaan berpengaruh terhadap kinerja karyawan (studi pada karyawan pengguna komputer dengan sistem operasi Ubuntu di 
PT. Pegadaian [Persero] Kanwil I Medan)" sehingga hipotesis tersebut dapat diterima.

2. Setelah dilakukan uji hipotesis secara parsial (Uji t) variabel pelatihan $\left(\mathrm{X}_{2}\right)$ secara parsial berpengaruh terhadap kinerja karyawan $(\mathrm{Y})$. Hal ini mendukung hipotesis yang menyatakan bahwa "Pelatihan berpengaruh terhadap kinerja karyawan (studi pada karyawan pengguna komputer dengan sistem operasi Ubuntu di PT. Pegadaian [Persero] Kanwil I Medan)" sehingga hipotesis tersebut dapat diterima.

3. Setelah dilakukan uji hipotesis secara parsial (Uji t) variabel pengembangan $\left(\mathrm{X}_{3}\right)$ secara parsial berpengaruh terhadap kinerja karyawan (Y). Hal ini mendukung hipotesis yang menyatakan bahwa "Pengembangan berpengaruh terhadap kinerja karyawan (studi pada karyawan pengguna komputer dengan sistem operasi Ubuntu di PT. Pegadaian [Persero] Kanwil I Medan)" sehingga hipotesis tersebut dapat diterima.

4. Setelah dilakukan uji hipotesis secara Simultan (Uji F) variabel pembinaan $\left(\mathrm{X}_{1}\right)$ pelatihan $\left(\mathrm{X}_{2}\right)$ dan pengembangan $\left(\mathrm{X}_{3}\right)$ secara bersama berpengaruh positif dan siknifikan terhadap kinerja karyawan (Y). Hal ini mendukung hipotesis yang menyatakan bahwa "Pembinaan, pelatihan, dan pengembangan berpengaruh secara simultan terhadap kinerja karyawan (studi pada karyawan pengguna komputer dengan sistem operasi Ubuntu di PT. Pegadaian [Persero] Kanwil I Medan)" sehingga hipotesis tersebut dapat diterima.

\section{DAFTAR PUSTAKA}

Arikunto, S. 2010. Prosedur penelitian : Suatu Pendekatan Praktik. (Edisi Revisi). Jakarta : Rineka Cipta.

Hamalik, Oemar. 2007. Manajemen Pelatihan Ketenagakerjaan. Jakarta: Bumi Aksara.

Handoko, T. Hani. 2001. Manajemen Personalia dan Sumber Daya Manusia.Yogyakarta : BPFE.

Harsuku, R. 2011. Mendongkrak motivasi dan kinerja. Malang: Universitas Brawijaya Press.

Hasibuan, S.P, Malayu. 2008. Sumber Daya Manusia, Edisi Revisi, Cetakan Kesebelas. Jakarta: Bumi Aksara.

Hersona, dkk.(2012). Analisis Pengaruh Pengembangan SDM Terhadap Kinerja Pegawai Pada Badan Kepegawaian Daerah Kabupaten Karawang. Jurnal Manajemen Vol.09 No.3, hlm. 717-729

Kambey, S.F.L. (2013). Pengaruh Pembinaan, Pelatihan, dan Pengembangan,

Pemberdayaan dan Partisipasi terhadap Kinerja Karyawan. Jurnal Studi Manajemen dan Organisasi, 10 (2), hlm.142151.

Kaswan.2012. Manajemen Sumber Daya Manusia untuk Keunggulan Bersaing Organisasi. Edisi Pertama. Cetakan Pertama. Yogyakarta : Graha Ilmu.

Mangkunegara, Anwar Prabu. 2004. Manajemen sumber daya manusia perusahaan edisi kelima. Bandung : PT. Remaja Rosdakarya. 
Moeheriono. 2009. Pengukuran Kinerja Berbasis Kompetensi. Bogor : Ghalia Indonesia.

Moekijat. 1991. Latihan dan Pengembangan Sumber Daya Manusia. Bandung: PT. Mandar Maju.

Mulyadi. 2004. Akuntansi Manajemen: Konsep, Manfaat, dan Rekayasa. Edisi Ketiga. Cetakan Ketiga. Jakarta: Salemba Empat.

Nugroho,Eko dkk. (2012). "The Influence of Coaching on Work Motivation and Individual Performance (A Case Study On Employess at Support Service Unit of Service Production Depertement Nickel Indonesia Tbk)".Jurnal Manajemen dan Bisnis, Vol 3 (2).

Riani, A.L. 2011.Budaya Organisasi. Edisi Pertama. Cetakan Pertama. Yogyakarta : Penerbit Graha Ilmu.

Rivai, V.2004. Manajemen Sumber Daya Manusia untuk Perusahaan.Dari Teori ke Praktik.Jakarta : PT Raja Grafindo Persada.

Rivai, V. dan E.J. Sagala.2009.Manajemen Sumber Daya Manusia untuk Instansi. Edisi Kedua. Jakarta : PT Raja Grafindo Persada.

Roziqin, Muhammad Zainur. 2010. Kepuasan Kerja. Malang : Averroes Press.

Salim, Gendro.2014. Effective Coaching. Jakarta: PT. Buana Ilmu Populer.

Salmah, Ninin Non Ayu. (2012). "Pengaruh Program Pelatihan dan Pengembangan Karyawan terhadap

Kompetensi
Karyawan pada PT. Muba Electric Power Sekayu".Jurnal Ekonomi dan Informasi Akuntansi (Jenius), Vol 2 (3).

Simamora, Henry. 2001. Manajemen SDM. Yogyakarta : STIE YKPN.

Sinambela, P. L. 2012. Kinerja Pegawai. Yogyakarta: Graha Ilmu.

Sofyandi, Herman. 2013. Manajemen Sumber Daya Manusia. Yogyakarta: Graha Ilmu.

Sugiono. 2011. Sebuah Pengantar, Aplikasi Untuk Riset. Bandung : Alfabeta

Sunarto.2005. Mengelola Karyawan.Yogyakarta Amus.

Sunyoto, Danang. 2012. Manajemen sumber Daya manusia. Jakarta : PT. Buku Seru.

Tohardi, Ahmad. 2002.Pemahaman Praktis Manajemen Sumber Daya Manusia. Bandung: Mandar Maju.

Wibowo. 2007. Manajemen Kinerja, Edisi Kedua. Jakarta : Rajagrafindo Persada.

Wijaya, Toni. 2009. Analisis Data Penelitian Menggunakan SPSS.Yogyakarta : Univ. Atma Jaya. 